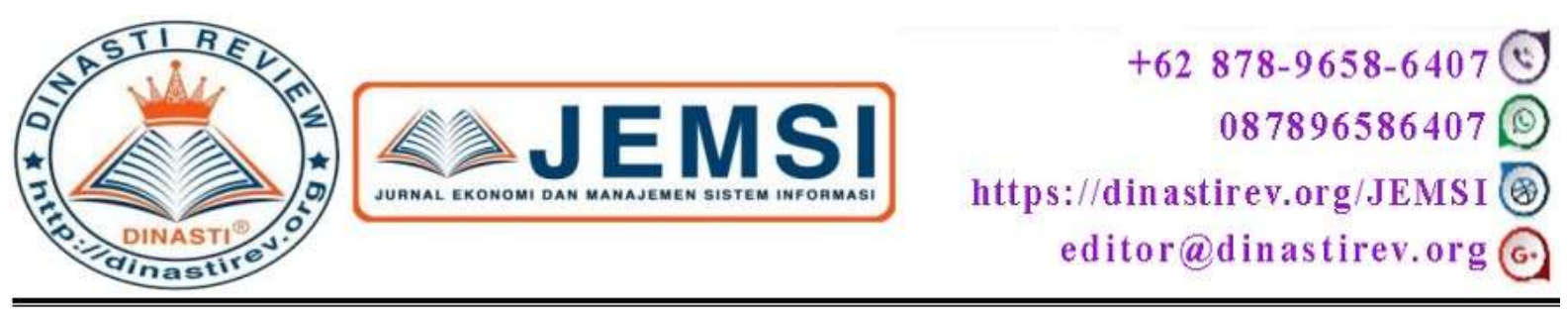

\title{
STRATEGIC MANAGEMENT ANALISIS SWOT \\ Pada PT. Gajah Tunggal Tbk
}

Lathif Hanafi Fadli

Universitas Mercu Buana, Jakarta, Indonesia

ARTICLE INFORMATION
Received: 20 November 2019
Revised: 24 November 2019
Issued: 30 November 2019
(filled in by Editor)

Corresponding author: first author

E-mail:

lathifhanafifadli@gmail.com

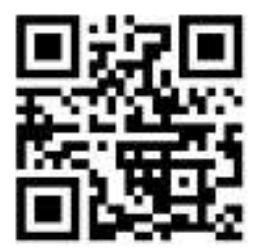

DOI:10.31933/JEMSI
Abstrak: Department PT Gajah Tunggal adalah salah satu perusahaan yang bergerak dala $\mathrm{m}$ sektor industri otomotif dan komponen khususnya produksi ban turut memberikan konstribusi terhadap perkembangan industri dalam negeri. PT Gajah Tunggal harus meningkatkan daya saingnya seiring dengan meningkatnya tantangan global. Dengan melaku kan analisa daya saing menggunakan metode SWOT analysis, diharapkan dapat mengetahui kekuatan posisi bisnis PT Gajah Tunggal terhadap para pesaing nya. Tujuan penulis ini adalah untuk mendapatkan subyek data apa yang perlu diketahui o leh PT Gajah Tunggal setelah mempelajari kondisi perusahaan, perkembangan pasar ban dan persaingan industri ban melalui analisa yaitu membandingkannya dengan SWOT analysis meliputi Strengths (Kekuatan), Weaknesses (Kelemahan), Opportunities (Peluang), Threats (Hambatanyang dimiliki oleh PT. Gajah Tunggal dalam upaya memperoleh keunggulan bersaing. Hasil analisa dapat disimpulkan bahwa saat ini PT.Ga jah Tunggal Tbk me miliki strategi yang baik dala $\mathrm{m}$ me manfaat kan potensi-potensi yang dimiliki perusahaan untuk memperoleh keunggulan bersaing yaitu dengan menggunakan strategi kompetitif menggunakan [matrik SWOT dan strategi diversifikasi (produk pasar) Strengths (Kekuatan) Opportunities (Peluang), Weak nesses (Kelemahan) Opportunities (Peluang), Strengths (Kekuatan) Threats (Hambatan), Weak nesses (Kelemahan) Threats (Hambatan)

Kata Kunci: Analisis Swot, Strategi K Ompetitif 


\section{PENDAHULUAN}

Industri otomotif dan komponennya merupakan salah satu sub sektor industri di Indonesia yang berkembang pesat dalam periode tiga tahun terakhir, peran industri otomotif dan komponennya ternyata memberi kontribusi yang cukup besar terhadap perekonomian Indonesia. Pengembangan industri otomotif dan komponennya perlu untuk terus dilakukan karena memiliki keterkaitan yang luas dengan sektor ekonomi lainnya serta memiliki potensi pasar dalam negeri yang cukup besar. Pada era globalisasi saat ini dibutuhkan strategi yang tepat untuk membangun sektor industri, agar dapat mewujudkan industri yang tangguh dan berdaya saing baik di pasar domestik maupun di pasar global, sehingga mampu mendorong tumbuhnya perekonomian, menyerap tenaga kerja, meningkatkan pendapatan masyarakat yang pada gilirannya akan mengurangi pengangguran dan kemiskinan. Dengan demikian akan turut memberikan andil membantu pemerintah dalam mensejahterakan penduduk Indonesia.

Salah satu industri yang memiliki potensi danperkembangan yang pesat adalah industri ban. Pada tahun 2013, Industri ban nasional mengalami peningkatan penjualan ban sebesar 5 persen dari 96,57 juta unit ban pada tahun 2012 menjadi 101,43 juta unit ban (APBI, 2013). Angka tersebut didapat dari hasil penjualan ban mobil yang mencapai 47,26 juta unit ban serta penjualan ban motor yang mencapai 54,16 juta unit ban.

Penjualan ban sangat berkaitan dengan industri otomotif. Pada tahun 2013, terjadi peningkatan penjualan sebesar $10,2 \%$ menjadi 1,4 juta unit mobil dari tahun sebelumnya. Sementara itu,di tahun yang sama tercatat total penjualan ban motor sebesar 54,16 juta unit ban di mana angka tersebut meningkat sebesar 16,4\% dari total penjualan pada tahun 2012 yaitu 47,04 juta unit ban.

PT Gajah Tunggal Tbk sebagai salah satu perusahaan yang bergerak dalam sektor industri khususnya pada sub sektor otomotif dan komponen memberikan konstribusi dalam menyediakan lapangan pekerjaan. Selain penyediaan lapangan kerja, PT Gajah Tunggal juga memenuhi kebutuhan konsumtif masyarakat, terlihat dari produksi andalan ban yang bermutu tinggi untuk kendaraan seperti mobil dan motor, juga untuk inner tubes, dan juga industrial. PT. Gajah Tunggal juga menjadi produsen dan distributor produk karet yang berkenaan antara lain benang ban, ban dalam, flap, o-ring, karet sintetis, dan masih banyak lagi.

PT Gajah Tunggal Tbk hingga kini dinilai masih menguasai pangsa pasar dan menjadi pemimpin pasar pada beberapa segmen ban yaitu ban sepeda motor jenis IRC dan ban bias untuk bus dan truk. Agar dapat terus tampil sebagai produsen ban terkemuka dalam menghadapi persaingan kedepan terutama dengan hadirnya beberapa perusahaan asing yang bergerak dalam bisnis serupa di tanah air, maka PT Gajah Tunggal Tbk sebagai produsen ban terbesar di Indonesia tidak hanya siap tetapi harus mampu menerapkan strategi yang mendasari sehingga bisa terus bersaing. Munculnya beberapa pendatang baru dalam produksi ban terutama karena Indonesia merupakan pangsa pasar otomotif yang menjadi incaran berbagai industri otomotif dunia maka persaingan industri ban juga akan semakin ketat. Tentunya PT Gajah Tunggal Tbk harus lebih ekstra memanfaatkan berbagai peluang yang ada antara lain sumber daya manusia, sumber daya alam, kondisi negara yang paling demokrasidi antara negara-negara kawasan Asean, serta memiliki stabilitas yang tangguh, termasuk tingginya presentasi penjualan kendaraan di Indonesia. Penulisan ini juga ditujukan untuk mengetahui kesiapan PT Gajah Tunggal Tbk sebagai salah satu perusahaan produsen ban dalam menghadapi persaingan industri komponen otomotif. 
PT Gajah Tunggal Tbk berdiri sejak tahun 1951 memulai produksi bannya dengan ban sepeda, sejak itu perusahaan tumbuh menjadi produsen ban terpadu terbesar di Asia Tenggara. Kantor pusat berlokasi di Wisma Hayam Wuruk 10th Floor Jl. Hayam Wuruk No. 8 Jakarta. Perusahaan mengoperasikan lima pabrik ban dan ban dalam, serta dua pabrik yang memproduksi kain ban dan SBR (Styrene Butadiene Rubber) yang terkait dengan fasilitas produksi ban. Kelima pabrik ban dan pabrik kain ban ini berlokasi di Tangerang, sekitar 30 kilometer disebelah barat Jakarta, Indonesia. Sedangkan pabrik SBR milik Perusahaan berlokasi di komplek Industri Kimia di Merak, Banten, sekitar $90 \mathrm{~km}$ disebelah barat Jakarta. Kegiatan usaha (business activities) perusahaan meliputi produksi dan perdagangan ban dalam dan ban luar segala jenis kendaraan, juga memproduksi kain ban dan karet sintesis beserta olahan, yang merupakan komponen utama dalam pembuatan ban. Sebagian besar pendapatan perusahaan adalah dari penjualan ban di Indonesia dan luar negeri. Selain menjual kepada pihak ketiga, perusahaan juga memprod uksi kain ban dan karet sintetis digunakan untuk memproduksi ban sendiri, hal ini sebagai bagian dari strategi untuk mengintegrasikan secara vertikal sarana produksi untuk merasionalisasi biaya produksi. Pada tahun 2012 PT Gajah Tunggal Tbk memproduksi ban mencapai 36,7 juta unit terdiri dari segmen produk ban radial 11,0 juta, ban bias 4,3 juta dan ban sepeda motor 21,4 juta, dengan total penjualan Rp 12.447 miliyar. Hampir semua penjualan ekspor Gajah Tunggal adalah untuk pasar segmen penggantian (replacement market). Guna perluasan pasar maka PT Gajah Tunggal Tbk telah melakukan penjajakan ke beberapa negara khususnya untuk pasar OEM (Original Equipment Manufacturer).

PT Gajah Tunggal berkomitmen untuk terus meningkatkan kualitas produk, hal ini dibuktikan dengan prestasi kelulusan dalam sertifikasi mutu internasional, antara lain tahun 1995 menerima sertifikat ISO 9002 untuk sistem kendali mutu produksi ban radial, tahun 1997 pabrik ban radial menerima sertifikasi ISO 9001 untuk mutu sistem desain, pengembangan dan instalasi, tahun 2002 menerima sertifikat QS 9000 dari TUV Internasional yang merupakan penghargaan bergengsi pada industri otomotif, dan tahun 2005 menerima ISO/TS 16949 untuk peningkatan dari QS 9000, selanjutnya di bulan Juni 2009 mendapatkan sertifikasi ISO 14001:2004 dari TUV Nord untuk sistem manajemen Lingkungan Hidup. Sebagian besar biaya produksi PT Gajah Tunggal terdiri dari bahan baku yang mencapai $80 \%$, komponen lain terdiri dari energi $(7 \%)$, buruh $(6 \%)$, penyusutan $(3 \%)$ dan pengeluaran tambahan lainnya (4\%). Bahan baku utama yang digunakan dalam produksi ban adalah karet alam, karet sintetis, kain ban, karbon hitam, kawat baja dan bahan kimia untuk pengolahan karet lainnya. Kain ban dan karet sintetis diproduksi sendiri oleh PT Gajah Tunggal Tbk untuk memastikan keamanan pasokan dan meningkatkan kendali biaya, tetapi pasokan bahan kimia masih bergantung kepada supplier, seperti butadiene, styrene dan benang nilon.

\section{KAJIAN PUSTAKA}

\section{Penentuan Strategi}

Sebelum dikemukakan mengenai penentuan strategi kompetitif, terlebih dahulu akan dikemukakan pengertian dari strategi yang dikemukakan oleh:Rangkuti (2004:3), ${ }^{\text {cee }}$ strategi adalah alat untuk mencapai tujuan eee. Sedangkan menurut Hamel dan Prahalad (1995:4), ${ }^{\text {cee }}$ strategi adalah tindakan yang bersifat incremental (senantiasa meningkat) dan terus menerus dan dilakukan berdasarkan sudut pandang tentang apa yang diharapkan oleh 
para pelangan di masa depan Richard L. Daft (2010:249) mendefinisikan strategi(strategy) secara eksplisit, yaitu rencana tindakan yang menerangkan tentang alokasi sumber daya serta berbagai aktivitas untuk menghadapi lingkungan, memperoleh keunggulan bersaing, dan mencapai tujuan perusahaan. Keunggulan bersaing (competitive advantege) adalah hal yang membedakan suatu perusahaan dari perushaan lain dan member ciri khas bagi perusahaan untuk memenuhi kebutuhan pasar konsumen. Inti perumusan strategi adalah menentukan bagaimana perusahaan kita akan berbeda dengan perusahaan lain. Strategi tentu saja berubah seiring waktu sesuai dengan kondisi lingkungan, namun agar tetap kompetitif Richard L. Daft membuat strategi perushaan yang berfokus kepada : Pemanfaatan kompetensi dasar, Mengembangkan sinergi Menciptkan Nilai Bagi Pelanggan. Analisis SWOT.

\section{Pengertian analisis SWOT}

Analisis SWOT (SWOT analysis) yakni mencakup upaya- upaya untuk mengenali kekuatan, kelemahan, peluang, dan ancaman yang menentukan kinerja perusahaan. Informasi eksternal mengeni peluang dan ancaman dapat diperoleh dari banyak sumber, termasuk pelanggan, dokumen pemerintah, pemasok, kalangan perbankan, rekan diperusahaan lain. Banyak perusahaan menggunakan jasa lembaga pemindaian untuk memperoleh keliping surat kabar, riset di internet, dan analisis tren-tren domestik dan global yang relevan (Richard L. Daft 2010:253) Selanjutnya Fredi Rangkuti (2004: 18) menjelaskan bahwa Analisis SWOT adalah identifikasi berbagai faktor secara sistematis untuk merumuskan strategi perusahaan. Analisis ini didasarkan pada logika yang dapat memaksimalkan kekuatan (strength) dan peluang (opportunity), namun secara bersamaan dapat meminimalkan kelemahan (weakness) dan ancaman(threats).

Proses pengambilan keputusan strategi selalu berkaitan dengan pengembangan misi, tujuan, strategi dan kebijakan perusahaan. Dengan demikian, perencanaan strategi harus menganalisa faktorfaktor strategi perusahaan (kekuatan, kelemahan, peluang dan ancaman) dalam kondisi yang saat ini.Analisis SWOT membandingkan antara faktor eksternal peluang (opportunity) dan ancaman (threats) dengan faktor internal kekuatan (strenght) dan kelemahan (weakness).

Unsur - unsur SWOT yaitu Kekuatan (Strenght) ,Kelemahan (weakness) ,Peluang (Opportunity),Ancaman (Threats) Faktor eksternal dan internal Menurut (irham fahmi, 2013:260) untuk menganalisis secara lebih dalam tentang SWOT, maka perlu dilihat faktor eksternal dan internal sebagai bagian penting dalam analisis SWOT, yaitu: Faktor eksternal Faktor eksternal ini mempengaruhi terbentuknya opportunities and threats $(\mathrm{O}$ dan T). Dimana faktor ini menyangkut dengan kondisi-kondisi yang terjadi di luar perusahaan yang mempengaruhi dalam pembuatan keputusan perusahaan. Faktor ini mencakup lingkungan industri dan lingkungan bisnis makro, ekonomi, politik, hukum, teknologi, kependudukan, dan sosial budaya. Faktor internal Faktor internal ini mempengaruhi terbentuknya strenghts and weaknesses ( $\mathrm{S}$ dan $\mathrm{W})$. Dimana faktor ini menyangkut dengan kondisi yang terjadi dalam perusahaan, yang mana ini turut mempengaruhi terbentuknya pembuatan keputusan (decision making) perusahaan.

\section{Model Analisis SWOT}

Analisis SWOT membandingkan antara faktor eksternal peluang dan ancaman dengan faktor internal kekuatan dan kelemahan. Faktor internal dimasukan kedalam matrik yang disebut matrik faktor strategi internal atau IFAS (Internal Strategic Factor Analisis Summary). Faktor eksternal dimasukkan kedalam matrik yang disebut matrik faktor 
strategi eksternal EFAS (Eksternal Strategic Factor Analisis Summary). Setelah matrik faktor strategi internal dan eksternal selesai disusun, kemudian hasilnya dimasukkan dalam model kuantitatif, yaitu matrik SWOT untuk merumuskan strategi kompetitif perusahaan.

\section{Matrik SWOT}

Alat yang dipakai untuk menyusun faktor- faktor strategis perusahaan adalah matrik SWOT. Matrik ini dapat mengambarkan secara jelas bagaimana peluang dan ancaman eksternal yang dihadapi perusahaan dapat disesuaikan dengan kekuatan dan kelemahan yang dimilikinya. Matrik ini dapat menghasilkan 4 set kemungkinan alternatif strategis. Strategi SO (Strength-Opportunities) Strategi ini dibuat berdasarkan jalan pikiran perusahaan, yaitu dengan memanfaatkan seluruh kekuatan untuk merebut dan memanfaatkan peluang yang sebesarbesarnya Adapun unsur Analisis SWOT diantaranya:

1. Kekuatan (Strength) Analisis terhadap unsur kekuatan yang dimiliki oleh perusahaan. Misalnya saja menganalisis tentang kelebihan apa saja yang dimiliki perusahaan seperti dari segi teknologi, kualitas hasil produksi, lokasi strategis, atau unsur kekuatan lainnya yang lebih menekankan pada keunggulan perusahaan. Biasanya dalam analisis SWOT perusahaan cenderung akan membuat sebanyak mungkin daftar kekuatan sebagai upaya kompetisi.

2. Kelemahan (Weakness) Selain melihat unsur kekuatan perusahaan, sangat penting untuk mengetahui apa kelemahan yang dimiliki perusahaan. Untuk mengetahui kelemahan perusahaan bisa dengan melakukan perbandingan dengan pesaing seperti apa yang dimiliki perusahaan lain namun tidak dimiliki perusahaan Anda. Jika ingin membuat daftar kelemahan perusahaan secara lebih obyektif bisa dengan testimoni konsumen yang umumnya lebih mengetahui apa yang kurang dari sebuah perusahaan.

3. Peluang (Opportunity) Unsur peluang biasanya dibuat pada saat awal membangun bisnis. Ini karena bisnis dibentuk berdasarkan peluang atau kesempatan untuk menghasilkan keuntungan. Unsur peluang termasuk daftar apa saja yang memungkinkan bisnis mampu bertahan dan diterima di masyarakat, baik dalam jangka pendek maupun jangka panjang.

4. Ancaman (Threats) Analisis terhadap unsur ancaman sangat penting karena menentukan apakah bisnis dapat bertahan atau tidak di masa depan. Beberapa hal yang termasuk unsur ancaman misalnya banyaknya pesaing, ketersediaan sumber daya, jangka waktu minat konsumen, dan lain sebagainya. Membuat daftar ancaman perusahaan bisa untuk jangka pendek maupun jangka panjang serta bisa sewaktu-waktu bertambah atau berkurang.

Matriks Kekuatan-Kelemahan-Peluang-Ancaman atau Matriks SWOT (Strengths Weakness Opportunities Threats SWOT Matrix) adalah alat yang dapat membantu manajer mengembangkan empat tipe strategi: SO (kekuatan peluang strengths opportunities), WO (kelemahan peluang weaknesses opportunities), ST (kekuatan ancaman strengths threats), WT (kelemahan ancaman weaknesses threats). Mencocokkan faktor eksternal dan internal kunci adalah bagian yang paling sulit dalam mengembangkan Matriks SWOT dan membutuhkan penilaian yang baik dan tidak ada pencocokan yang terbaik .

\section{Merumuskan Strategi Kompetitif}

Cara yang efektif untuk merumuskan strategi adalah lima kekuatan dan strategi kompetitif (Porter. Michael E Porter :259) meneliti sejumlah perusahaan dan menyatakan bahwa strategi tingkat- usaha merupakan hasil dari lima kekuatan kompetitif dilingkungan 
perusahaan. Lima Kekuatan Kompetitif Porter Kekuatan - kekuatan kompetitif yang ada dilingkungan perusahaan dan menunjukan pengaruh teknologi internet terhadap setiap kekuatan. Kekuatan-kekuatan ini membantu menentukan posisi perusahaan versus pesaingnya di dunia industri. Potensi pesaing baru. Daya tawar pembeli Daya tawar pemasok Ancaman produk pengganti, Pesaing antar kompetitor.

\section{METODE PENELITIAN}

Analisis dalam penelitian ini adalah dengan menggunakan analisi SWOT, dimana metode ini menunjukan kinerja perusahaan dengan menentukan kombinasi faktor internal dan eksternal. Analisis SWO T membandingkan antara faktor internal, yaitu kekuatan (strength), dan kelemahan (weakness). Dengan faktor eksternal yaitu peluang (opportunity), dan ancaman (threats). Faktor internal dimasukan kedalam matrik yang disebut matrik faktor IFAS (Internal Strategic Faktor Analisis Summary). Faktor eksternal dimasukan kedalam matrik yang disebut matrik faktor eksternal atau EFAS (Eksternal Strategic Faktor Analisis Summary). Setelah matrik faktor strategi internal dan eksternal selesai disusun kemudian hasilnya dimasukan kedalam model kualitatif yaitu matrik SWOT untuk merumuskan strategi kompetitif perusahaan.

\section{HASIL DAN PEMBAHASAN}

\section{Hasil penelitian}

Dari hasil analisa SWOT meliputi kekuatan, kelemahan, peluang serta ancaman pada PT. Gajah Tunggal Tbk (PT.GT) adalah sebagai berikut:

Strengths (Kekuatan)

○ Merupakan pemimpin pasar pada produk ban sepeda motor saat ini (Top Market Share)

- Mempunyai divisi atau anak perusahaan yang mendukung untuk memproduksiban yang berguna untuk mengurangi biaya produksi perushaan.

- Memiliki produk-produk yang unik dan berbeda dari pesaingnya, seperti Champiro ECO (ban ramah lingkungan), Winter Pro, Winter Pro HP (Ban salju/musimdingin), Smoke Tire (ban drifting multi warna)

- Memiliki sumberdaya manusia yang professional, terpercaya, kompeten dan tekun yang sebagian besar karyawannya telah bergabung dengan perushaan sejak lam sebagai kunci bagi perusahaan mencapai visinya.

- Berkomitmen untuk program tanggung jawab sosial perusahaan (CSR) dengan program mengembangkan empat pilar (kesehatan, pendidikan, pengembangan masayarakat dan lingkungan) yang bertujuan untuk mendekatkan diri kepada masyarakat.

- Mendapatkan banyak p pengahrgaa yang telah diakui dunia (Best Vendor performance Suzuki 2017. Motor Plus Reader choice Award 2017, proton Suppliers Award 2017, HINO Aaward 2017, Indonesi WOW Brand Awards 2017, Indonesia Most Innovative Bussines Award 2017, Forbes Award 2017 dll)

- Memilki perputaran barang yang cukup cepat

- Memilki rasio likuiditas yang cukup baik diandingkan denganpesaingnya

- Memiliki jaringan kuat dalam dan luar negeri Weaknesses (Kelemahan) 
- Sewaktu-waktu dapat mengalami kerugian karena hutang akibat nilai tukar USD terhadap rupiah yang tidak menentu.

- Harga Bahan Baku (karet alam) yang cenderung meningkat menjadi suatu beban perusahaan.

○ Perputaran piutang yang menurun dan semakin lamabta untuk dikonversi menjadi kas.

Opportunities (Peluang)

○ Perusahaan merupakan perusahaan yang sudah dikenal di Indonesia dan mancanegara.

- Akses situs internet www.gt-tires.com untuk memudahkan akses informasi dan publikasi perusahaan dan situs internet www.gtintranet.com yang berakitan dengan controlling quality untuk para pemegang saham dan masyarakat umum yang ingin berinvestasi.

- Acara-Acara rutin yang diselenggarakan oleh PT.GT Tbk berupa acara-acara otomotif yang ikut serta mendukung didalam sektor penjualan perusahaan dan brand awareness

- Meningkatnya penjualan kendaraan bermotor tahun demi tahun yang mempengaruhi kegiatan produksi perushaan dan pasar OE

- Banyakanya perusahaan asing yang tertarikbekerjasama.

Threats (Hambatan)

o Persaingan industry yang sejenis dengan perusahaan lain yangcukup ketat

- Meningkatnya harga bahan baku yang memberatkan perusahaan

o Kurs mata uang rupiah terhadap dolar yang tidak menentu.

○ Produk pesiang memilki harga bersaing

- Ban motor yang diimpor secara illegal merupakan ancaman bagi perusahaan karena harga ban impor yang lebih murah (Battlax, Michellin, Pirelli)

○ Konsumen yang lebih memilih produk ban import (Toyo tirel Jepang, Cooper Tirel Amerika, Eropa (continental (Jerman, Nokian\ finlandia)

\section{Pembahasan Hasil Penelitian}

Setelah mengetahui kekuatan, kelemahan, peluang dan ancaman pada PT Gajah Tunggal Tbk berikutnya akan dianalisa terhadap faktor- faktor tersebut untuk mendapatkan gambaran lebih lanjut mengenai kondisi pada produk PT Gajah Tunggal Tbk pada masyarakat sehinga dapat ditentukan strategi dan langkah- langkah yang dapat diterapkan dimasa- masa mendatang.

Langkah awal tahap analisa terhadap faktorfaktor kekuatan, kelemahan, peluang dan ancaman produk PT. Gajah Tunggal Tbk adalah dengan melakukan analisa melalui matrik IFAS (Internal Strategic Faktor Analisis Summary) dan EFAS (Eksternal Strategic Faktor Analisis Summary) Selanjutnya dari hasil analisa dengan menggunakan matrik IFAS dan EFAS akan dianalisis dengan menggunakan matrix SWOT untuk mendapatkan gambaran akhir kedudukan produk PT. Gajah Tunggal Tbk dengan produk-produk sejenis dari perusahaan lain. Matrik Faktor Strategi Internal (IFAS) Dan Matrik Faktor Strategi Eksternal (EFAS). Setelah faktor- faktor strategi internal dan eksternal suatu perusahaan diidentifikasi, suatu table IFAS dan IFAS disusun untuk merumuskan faktor- faktor 
strategi internal tersebut dalam kerangka Strenght and Weakness Perusahaan PT. Gajah Tunggal Tbk.

Selanjutnya untuk menyusun formulasi alternatif-alternatif strategi PT. Gajah Tunggal Tbk mempergunakan matrik SWO T. Alternatif-alternatif strategi disusun berdasarkan interaksi atas faktor internal dan eksternal perusahaan untuk memperoleh strategi kompetitif. Beberapa alternatif strategi yang dapat dilakukan oleh perusahaan.

Berdasarkan hasil analisis dengan menggunakan matrik SWOT dari beberapa faktor internal, berupa kekuatan dan kelemahan, serta faktor eksternal berupa peluang dan ancaman untuk menentukan strategi kompetitif bagi PT.Gajah Tunggal Tbk adalah dengan melakukan strategi diversifikasi (produk, pasar), yaitu:

Strengths (Kekuatan) - Opportunities (Peluang)

- Mengembangkan kegiatan ekspor perusahaan untuk meningkatkan market share.

- Mengadakan dan menambahkan acara-acara yang bertujuan untuk menjalin komunikasi antara perushaan dankonsumen.

- Menjalin kerjasaman dengan produsen kendaraan bermotor di Indonesia dengan menawarkan hraga yang bersaing dibandingkan dengan perusahaan lainnya

○ Memanfaatkan teknologi dalam upaya mengenalkan, memasrkan dan mempertahankan produk dipasaran.

Weaknesses (Kelemahan) - Opportunities (Peluang)

○ Mengontrol hutang perusahaan dan kualitas produk yang dapat dilihat oleh pengguna situs internet perushaan.

- Meberikan diskon bagi pembelian tunai pada pasar domestik yang sednag meningkat untuk mengatasi perputaran piutang yang melemah.

○ Melakukan kerjasama yang mengikat terkait dengan supply bahan baku.

Strengths (Kekuatan) - Threats (Hambatan)

○ Mengadakan prorgam-program intensif penjualan seperti pemasaran untuk memberikankesadaran akan merek GT radial dan IRC secara efektif dan efisien.

- Melakukan kerjasama yang baik dengan cutomer seperti memberikan fasilitas perawatan ban terhadapa customer yang bersedia menjadi pratner dalam mengiklankan produk PT.Gajah Tunggal Tbk.

- Tetap berinovasi dalam menghasilkan produk -produk unggulan uantuk dapat berasing dengan industrysejenis.

Weaknesses (Kelemahan) - Threats (Hambatan)

- Mengontrol biaya produksi dan operasional perusahaan untuk meningkatkan laba perusahaan.

○ Memberikan kesadaran masyarakat untuk dapat memakai produk dalam negeri.

\section{KESIMPULAN DAN SARAN}

Setelah penulis mempelajari keadaan yang terjadi pada perusahaan, bahwa saat ini PT.Gajah Tunggal Tbk memiliki strategi yang baik dalam memanfaatkan potensi-potensi yang dimiliki perusahaan untuk memperoleh keunggulan bersaing. Penulis juga menyarankan agar perusahaan memperhatikan hal- hal sebagai berikut :

Strengths (Kekuatan)

Perusahaan harus tetap menjaga dan mempertahankan pelayanan yang berkualitas yang diberikan perusahaan kepada konsumen, agar tidak mempengaruhi minat konsumen. 
Perusahaan harus tetap berinovasi dalam menc iptakan produk-produk baru yang memiliki keunggulan bersaing.

Weaknesses (Kelemahan)

Perusahaan sebaiknya lebih berhati- hati dalam pengaturan piutang dan mengatisipasi adanya shortage raw materials serta melakukan perawatan mesin secara rutin agar tidak mengalami kegagalan atau kecacatan produk yang dapat mempengaruhi kepuasan konsumen. Opportunities (Peluang)

Perusahaan harus pandai dalam mengambil peluang atau kesempatan pemilihan strategi terbaik yang dapat diterapkan oleh perusahaan yaitu dengan strategi kompetitif yakni menggunakan kekuatan-kekuatan yang dimiliki PT. Gajah Tunggal Tbk untuk memanfaatkan peluang jangka panjang.

Threats (Hambatan)

Perusahaan harus lebih meningkatkan kualitas dan daya jangkau yang luas agar dapat bersaing dengan perusahaan lain serta terhindar dari ancaman-ancaman perusahaan lain yang semakin bermunculan.

\section{DAFTAR RUJUKAN}

Hapzi Ali, Strategic Management; Analisis LIngkungan Internal Organisasi (resourcesbased view and value chain management), SWOT Analysis, SWOT Matrix dan IE Matrix, Mercubuana University, 2019

Freddy Rangkuti, Analisis SWOT Teknik Membedah Kasus Bisnis, PT. Graedia, Jakarta, 2004

Richard L. Daft, Era Baru Manajemen,Edward Tanujaya, Edisi 9,Salemba Empat,2010

Nisak, Zuhrotun, "Analisis SWOT Untuk Menentukan Stratregi Kompetitif, dalam http://journal.unisla.ac.id/index.php?p=journal\&id=122, diunduh 17-Juli-2019

Kartajaya, Hermawan, 2013. "Competition In Spare Parts Industry: When Indonesia Becomes One Of The Biggest Markets In Asean" Mark Plus Consulting 2013.

Kementrian Perindustrian RI, 2013. "Mengukur Kesiapan Industri Nasional Jelang AEC 2015" Media Industri No. 02.2013

Sugiyono (2013), "cee Statistika Untuk Penelitian" ". ALFABETA.Bandung2013

https://www.gt-tires.com/indonesia/

Widiyarini, "Analisa Strategi Daya Saing menggunakan Five Forces Analysis pada PT Gajah Tunggal, SOSIO e-KONS Vol.7 No.1 Februari 2015, Fakultas Teknik Matematika dan IPA, Universitas Indraprasta PGRI, 2015. 